\title{
Regulation of Synaptic Rac1 Activity, Long-Term Potentiation Maintenance, and Learning and Memory by BCR and ABR Rac GTPase-Activating Proteins
}

\author{
Daeyoung Oh, ${ }^{1 \star}$ Seungnam Han, ${ }^{1 \star}$ Jinsoo Seo, ${ }^{2 *}$ Jae-Ran Lee, ${ }^{3 *}$ Jeonghoon Choi, ${ }^{1}$ John Groffen, ${ }^{4}$ Karam Kim, ${ }^{1}$ \\ Yi Sul Cho, ${ }^{5}$ Han-Saem Choi, ${ }^{2}$ Hyewon Shin, ${ }^{1}$ Jooyeon Woo, ${ }^{1}$ Hyejung Won, ${ }^{1}$ Soon Kwon Park, ${ }^{6}$ Soo-Young Kim, \\ Jihoon Jo, ${ }^{8}$ Daniel J. Whitcomb, ${ }^{8}$ Kwangwook Cho, ${ }^{8}$ Hyun Kim, ${ }^{7}$ Yong Chul Bae, ${ }^{5}$ Nora Heisterkamp, ${ }^{4}$ Se-Young Choi, ${ }^{2}$ \\ and Eunjoon Kim ${ }^{1}$ \\ ${ }^{1}$ National Creative Research Initiative Center for Synaptogenesis and Department of Biological Sciences, Korea Advanced Institute of Science and \\ Technology, Daejeon 305-701, Korea, ${ }^{2}$ Department of Physiology and Dental Research Institute, Seoul National University School of Dentistry, Seoul \\ 110-749, Korea, ${ }^{3}$ Korea Research Institute of Bioscience and Biotechnology, Daejeon 305-806, Korea, ${ }^{4}$ Section of Molecular Carcinogenesis, Division of \\ Hematology/Oncology and The Saban Research Institute of Childrens Hospital, Los Angeles, California 90027, ${ }^{5}$ Department of Anatomy and Neurobiology, \\ BK21, School of Dentistry, Kyungpook National University, Daegu 700-412, Korea, ${ }^{6}$ School of Alternative Medicine and Health Science, Jeonju University, \\ Jeonju 520-759, Korea, ${ }^{7}$ Department of Anatomy and Division of Brain Korea 21 Biomedical Science, College of Medicine, Korea University, Seoul 136-701, \\ Korea, and ${ }^{8}$ Henry Wellcome Laboratories for Integrative Neuroscience and Endocrinology, Faculty of Medicine and Dentistry, University of Bristol, Bristol \\ BS1 3NY, United Kingdom
}

Rho family small GTPases are important regulators of neuronal development. Defective Rho regulation causes nervous system dysfunctions including mental retardation and Alzheimer's disease. Racl, a member of the Rho family, regulates dendritic spines and excitatory synapses, but relatively little is known about how synaptic Racl is negatively regulated. Breakpoint cluster region (BCR) is a Rac GTPase-activating protein known to form a fusion protein with the c-Abl tyrosine kinase in Philadelphia chromosome-positive chronic myelogenous leukemia. Despite the fact that BCR mRNAs are abundantly expressed in the brain, the neural functions of BCR protein have remained obscure. We report here that BCR and its close relative active BCR-related (ABR) localize at excitatory synapses and directly interact with PSD-95, an abundant postsynaptic scaffolding protein. Mice deficient for BCR or ABR show enhanced basal Racl activity but only a small increase in spine density. Importantly, mice lacking BCR or ABR exhibit a marked decrease in the maintenance, but not induction, of long-term potentiation, and show impaired spatial and object recognition memory. These results suggest that $\mathrm{BCR}$ and $\mathrm{ABR}$ have novel roles in the regulation of synaptic Rac1 signaling, synaptic plasticity, and learning and memory, and that excessive Racl activity negatively affects synaptic and cognitive functions.

\section{Introduction}

Neuronal development involves diverse molecular and cellular events including the morphogenesis of dendrites and dendritic spines. Rho family small GTPases regulate dendritic and spine development (Carlisle and Kennedy, 2005; Ethell and Pasquale,

\footnotetext{
Received April 2, 2010; revised Aug. 4, 2010; accepted Aug. 24, 2010.

This work was supported by the National Creative Research Initiative Program of the Korean Ministry of Education, Science and Technology (E.K.), Neuroscience Program Grant 2009-0081468 (S.-Y.C.), 21st Century Frontier R\&D Program in Neuroscience Grant 2009K001284 (H.K.), Basic Science Research Program Grant R13-2008-009-01001-0 (Y.C.B.), and United States Public Health Service Grants HL071945 (J.G.) and HL060231 (J.G., N.H.). We thank Dr. Owen Witte (University of California, Los Angeles, Los Angeles, CA) for the human BCR CDNA and Dr. Louis Lim (University College London, London, UK) for the human ABR CDNA.

${ }^{*}$ D.O., S.H., J.S., and J.-R.L. contributed equally to this work.

Correspondence should be addressed to either of the following: Se-Young Choi, Department of Physiology and Dental Research Institute, Seoul National University School of Dentistry, Seoul, Korea, E-mail: sychoi@snu.ac.kr; or Eunjoon Kim, Department of Biological Sciences, Korea Advanced Institute of Science and Technology, Daejeon 305-701, Korea, E-mail: kime@kaist.ac.kr.

J.-R. Lee's present address: Korea Research Institute of Bioscience and Biotechnology, Daejeon 305-806, Korea. DOI:10.1523/JNEUROSCI.1711-10.2010

Copyright $\odot 2010$ the authors $\quad 0270-6474 / 10 / 3014134-11 \$ 15.00 / 0$
}

2005; Govek et al., 2005; Calabrese et al., 2006; Tada and Sheng, 2006), and defective Rho signaling is associated with mental retardation, Alzheimer's disease, and amyotrophic lateral sclerosis (Blanpied and Ehlers, 2004; Newey et al., 2005; van Galen and Ramakers, 2005; Boda et al., 2006; Zhao et al., 2006; Nadif Kasri and Van Aelst, 2008). Rac1, a well known Rho GTPase, regulates spine/synapse structure (Luo et al., 1996; Nakayama et al., 2000; Tashiro et al., 2000; Penzes et al., 2001; Zhang et al., 2003; Tashiro and Yuste, 2004; Carlisle and Kennedy, 2005; Tada and Sheng, 2006) and synaptic function (Lamprecht and LeDoux, 2004; Wiens et al., 2005; Haditsch et al., 2009; Rex et al., 2009).

Racl at excitatory synapses acts in concert with upstream regulators and downstream effectors. Known downstream effectors of synaptic Rac1 include p21-activated kinase (PAK) (Boda et al., 2006), IRSp53 (Soltau et al., 2002; Choi et al., 2005; Kim et al., 2009; Sawallisch et al., 2009), and WAVE (Wiskott-Aldrich syndrome protein family verprolin-homologous protein) (Choi et al., 2005; Pilpel and Segal, 2005; Kim et al., 2006). Activators of synaptic Rac1 that possess guanine nucleotide exchange factor (GEF) activity in- 
clude Kalirin-7 (Penzes et al., 2003; Xie et al., 2007), $\beta$ Pix (Park et al., 2003; Zhang et al., 2005; Saneyoshi et al., 2008), and Tiam1 (Tolias et al., 2005, 2007; Penzes et al., 2008). However, relatively little is known about inhibitors of synaptic Racl with GTPase-activating protein (GAP) activity. Recently, $\alpha 1$-chimaerin, a diacylglycerolbinding protein with Racl GAP activity, has been shown to inhibit dendritic spines in a diacylglycerol-dependent manner (Van de Ven et al., 2005; Buttery et al., 2006).

Breakpoint cluster region (BCR) was originally identified as a protein that forms a fusion protein with $\mathrm{c}-\mathrm{Abl}$ tyrosine kinase via Philadelphia chromosomal translocation, and thereby induces chronic myeloid leukemia (Groffen et al., 1984; Heisterkamp et al., 1985). BCR and its close relative active BCR-related (ABR) (Heisterkamp et al., 1989) show Rac GAP activities both in vitro and in vivo (Diekmann et al., 1991; Heisterkamp et al., 1993; Tan et al., 1993; Chuang et al., 1995; Voncken et al., 1995; Kaartinen et al., 2001; Cho et al., 2007). Importantly, BCR and ABR mRNAs are abundantly expressed in the brain (Heisterkamp et al., 1993). In addition, BCR and ABR double-null mice exhibit hyperactive astroglia and vestibular dysgenesis (Kaartinen et al., 2001, 2002), suggesting that $\mathrm{BCR}$ and $\mathrm{ABR}$ regulate neural development. However, their involvement in synaptic function/plasticity and higher brain functions has not been explored.

Here, we report that BCR and ABR proteins are mainly expressed in the brain, localize to excitatory synapses, and directly interact with PSD-95, an abundant postsynaptic scaffolding protein (Sheng and Hoogenraad, 2007). Our data from mice lacking BCR or ABR suggest novel involvements of these proteins in the regulation of neuronal Racl activity, long-term potentiation (LTP) maintenance, and learning and memory.

\section{Materials and Methods}

Constructs. BCR and ABR expression constructs were generated by subcloning full-length human BCR (amino acids 1-1271) and ABR (1-859) into pEGFP-C1 (Clontech). For pull down, the C-terminal regions of BCR (1059-1271) and ABR (665-859) were subcloned into pGEX4T-1. For yeast two-hybrid, fragments of BCR (1072-1271) and ABR (665859) were subcloned into pBHA.

Antibodies. H6-BCR (amino acids 1059-1271) and GST-ABR (650$859)$ were used to generate polyclonal BCR (1359 rabbit) and ABR (1388 rabbit) antibodies. The following antibodies were purchased: BCR N-20, BCR C-20, synaptophysin, c-Jun N-terminal kinase (JNK), phosphoJNK (Santa Cruz), ABR, pan-extracellular signal-regulated kinase (ERK) (BD Biosciences Transduction Laboratories), synapsin I (Millipore Bioscience Research Reagents), PAK1, PAK3, phospho-PAK1/3, phosphoERK1/2 (p44/42), p38 mitogen-activated protein kinase (MAPK), and phospho-p38 MAPK (Cell Signaling).

Animals. Male Sprague Dawley rats were used for experiments including dissociated hippocampal culture, immunoblot analysis, in vivo coimmunoprecipitation, and electron microscopy. $\mathrm{BCR}^{-1-}$ and $\mathrm{ABR}^{-1-}$ mice in genetic backgrounds of 50\% $129 \mathrm{~Sv}$ plus 50\% C57BL/6 and 50\% $129 \mathrm{~Sv}$ plus 50\% Black Swiss, respectively (Voncken et al., 1995; Kaartinen et al., 2001), were backcrossed with C57BL/6 females. Littermates were used as controls for spine analysis, LTP/long-term depression (LTD) analysis, and all behavioral assays.

In situ hybridization. Brain sections ( $12 \mu \mathrm{m}$ thick) from postnatal day 14 (P14) rats were used. BCR- and ABR-specific hybridization probes encompassing the $\mathrm{C}$ terminus and the $3^{\prime}$-untranslated region were prepared from the following constructs: pGEM-7Zf containing nucleotides 3965-4284 of rat BCR (coding region, nucleotides 131-3943) and nucleotides 3965-4284 of rat ABR (coding region, 251-2866). Antisense riboprobes were prepared using Riboprobe System (Promega) and $\left[\alpha-{ }^{35}\right.$ S $]$ UTP.

Electron microscopy. Hippocampal sections $(60 \mu \mathrm{m})$ from 10-week-old rats were incubated overnight with BCR (C-20) or ABR (BD) antibodies and biotinylated secondary antibodies for $2 \mathrm{~h}$. The sections were incubated with
ExtrAvidin peroxidase (Sigma-Aldrich), and the immunoperoxidase was revealed by nickel intensified 3,30-diaminobenzidine tetrahydrochloride. Sections were osmicated, dehydrated, embedded with Durcupan ACM (Fluka), and cured for $48 \mathrm{~h}$ at $60^{\circ} \mathrm{C}$. The area containing the pyramidal cell layer and stratum radiatum of the CA1 region was trimmed. Thin sections were cut, mounted on nickel grids, and stained with uranyl acetate and lead citrate. Grids were examined on a Hitachi H 7500 electron microscope (Hitachi) at $80 \mathrm{kV}$ accelerating voltage. Images were captured with Digital Montage software driving a MultiScan cooled CCD camera (ES1000W; Gatan) and saved as TIFF files.

Neuron culture, transfection, and immunocytochemistry. Cultured hippocampal neurons were prepared from embryonic day 18 rat hippocampi. Neurons were transfected by calcium phosphate transfection kit. For immunofluorescence staining, cultured neurons were fixed with $4 \%$ formaldehyde and $4 \%$ sucrose in PBS, and permeabilized with $0.2 \%$ Triton X-100 in PBS. Mouse brain sections $(50 \mu \mathrm{m})$ for immunostaining were perfused with $4 \%$ formaldehyde and permeabilized by $0.5 \%$ Triton X-100. ABR signals, but not BCR signals, were amplified by tyramide signal amplification (PerkinElmer Life Sciences).

Pull down of active Racl. Amount of active Racl was determined using the EZ-Detect Racl activation kit (Pierce). Mouse brains (3 4 weeks) were homogenized in the lysis/binding/washing buffer containing 320 mM sucrose, 10 mм Tris-HCl, $\mathrm{pH}$ 7.4, 5 mм EDTA, and protease inhibitors, followed by centrifugation. The supernatant was incubated with GST-PAK1-PBD (p21 binding domain) fusion proteins immobilized on glutathione-agarose bead at $4^{\circ} \mathrm{C}$ for $1 \mathrm{~h}$, followed by precipitation, washing, and immunoblotting with Rac1 monoclonal antibodies.

DiOlistic spine labeling. Hippocampal slices from 6-week-old mice were labeled by gene gun-mediated ballistic delivery of lipophilic dye DiI as described previously (Gan et al., 2000). $Z$-stacked images from the proximal stratum radiatum region of hippocampus were used for blind image analysis. Spines were defined by protrusions with a bulbous head wider than the neck and with length longer than $0.4 \mu \mathrm{m}$. Spine density was measured from 40 to $80 \mu \mathrm{m}$ segments of secondary dendrites on approximately one to two dendrites per neuron. The narrowest point in the spine neck was defined as the border between spine head and neck. MetaMorph software (Molecular Devices) was used for quantitative analysis.

Electrophysiology. LTP was induced in hippocampal slices (P21-P28) by four episodes of theta-burst stimulation with $10 \mathrm{~s}$ intervals. Thetaburst stimulation consisted of 10 stimulus trains delivered at $5 \mathrm{~Hz}$; each train consisted of four pulses at $100 \mathrm{~Hz}$. LTD was induced in hippocampal slices (P21-P28) by low-frequency stimulation (900 pulses at $1 \mathrm{~Hz}$ for $900 \mathrm{~s})$. Average responses ( \pm SEM) were expressed as percentage of baseline response (at least $10 \mathrm{~min}$ of stable responses). The experimenters were blind to mouse genotypes. Data were analyzed by using custom macros written in Igor (Wavemetrics). For whole-cell recordings, CA1 pyramidal cells (P21) were held at $-70 \mathrm{mV}$ using a MultiClamp 700B amplifier (Molecular Devices). Pipette solutions for miniature EPSCs (mEPSCs) contained the following (in mM): 110 Cs-gluconate, $30 \mathrm{CsCl}$, 20 HEPES, 4 MgATP, 0.3 NaGTP, 4 NaVitC, 0.5 EGTA (10 EGTA for AMPA vs NMDA receptor ratio). TTX $(0.5 \mu \mathrm{M})$ and bicuculline $(20 \mu \mathrm{M})$ were added to artificial CSF (ACSF) for mEPSC measurements. To obtain AMPA receptor-mediated EPSCs, neurons in ACSF with $100 \mu \mathrm{M}$ picrotoxin were held at $-70 \mathrm{mV}$ and stimulated at $0.066 \mathrm{~Hz}$. NMDA receptor-mediated EPSCs were isolated by changing the holding potential to $+40 \mathrm{mV}$ and adding $10 \mu \mathrm{M}$ CNQX to ACSF. The 25 30 EPSC samples were averaged to obtain the AMPA/NMDA EPSC ratio.

Morris water maze. In the water maze test, $\mathrm{BCR}^{-1-}$ male littermates (2-6 months of age) were trained to find the hidden platform in a 100$\mathrm{cm}$-diameter apparatus using three trials per day with intertrial intervals of $1 \mathrm{~h} ; \mathrm{ABR}^{-1-}$ male littermates were trained using two successive trials per day. Probe tests were performed $24 \mathrm{~h}$ after the last training session. Target quadrant occupancy and exact platform crossings were determined using Ethovision software (Noldus).

Novel object recognition. Novel object recognition tests were conducted in an open-field box on 4 successive days, with $10 \mathrm{~min}$ daily trials. For the first $2 \mathrm{~d}$, mice were allowed to explore an empty box for adaptation. On the third day, mice were presented with two different objects: A and B (sample phase). 
A

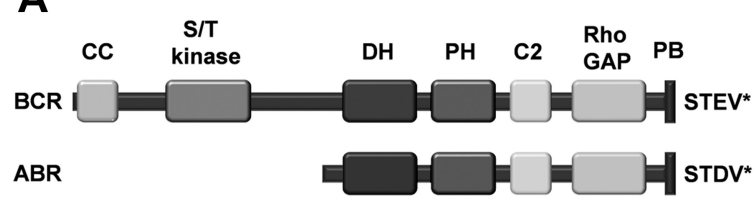

D

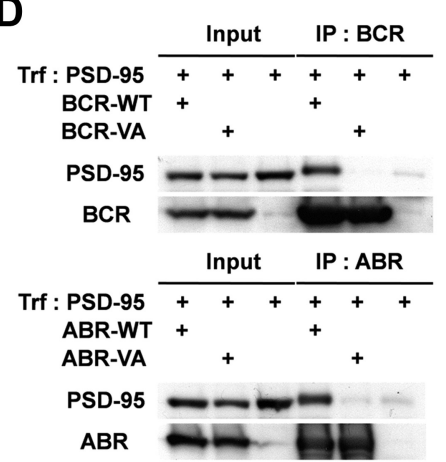

B

\begin{tabular}{|c|c|c|c|c|}
\hline \multirow{2}{*}{ Bait : } & \multicolumn{2}{|c|}{ BCR } & \multicolumn{2}{|c|}{ ABR } \\
\hline & WT & $\underline{V 1271 A}$ & WT & $\underline{\text { V859A }}$ \\
\hline Prey : & & & & \\
\hline PSD-95 PDZ 1-2 & +++ & - & +++ & - \\
\hline PSD-95 PDZ 3 & - & - & - & - \\
\hline SAP97 PDZ 1-2 & ++ & - & ++ & - \\
\hline SAP97 PDZ 3 & - & - & - & - \\
\hline PSD-93 PDZ 1-2 & ++ & - & ++ & - \\
\hline SAP102 PDZ 1-2 & ++ & - & ++ & - \\
\hline GRIP1 PDZ 4-6 & - & - & - & - \\
\hline pGAD10 alone & - & - & - & - \\
\hline
\end{tabular}

C

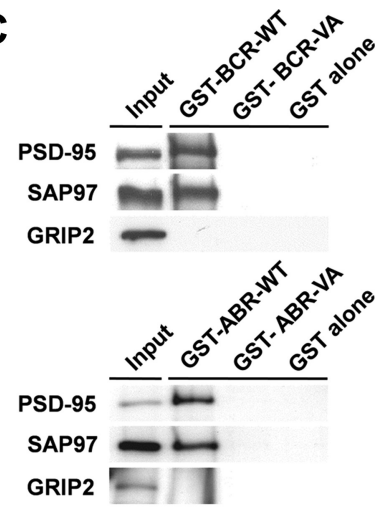

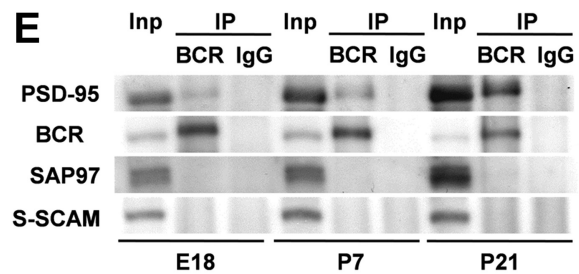
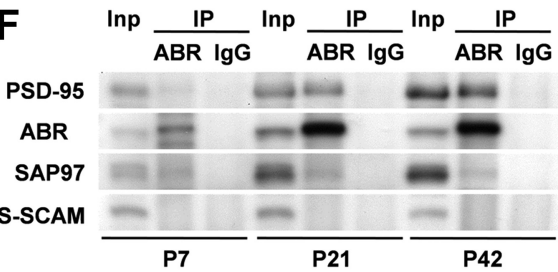

G
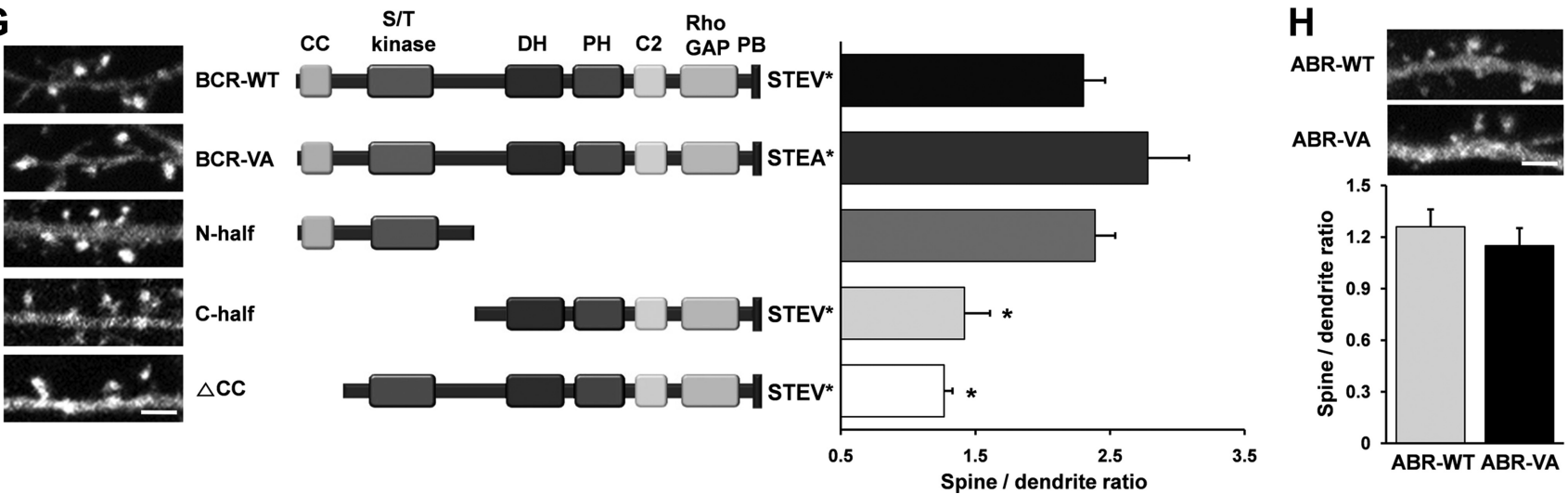

Figure 1. PSD-95 interacts with BCR and ABR but does not promote their synaptic localization. $A$, Domain structure of BCRand ABR. CC, Coiled coil; $S / T$ kinase, serine-threonine kinase; DH, Dbl homology; $P H$, pleckstrin homology; $C 2$, protein kinase C conserved region 2; PB, PDZ-binding motif that ends with STEV* or STDV*. B, The C termini of BCR and ABR interact with the first two PDZ domains of PSD-95 family proteins (PSD-95, PSD-93/chapsyn-110, SAP97, and SAP102) in yeast two-hybrid assays. GRIP1 PDZ4-6, A negative control. V1271A/V859A, A C-terminal point mutation. C, Pull down of PSD-95 and SAP97 expressed in HEK293T cells by GST-BCR/ABR. GRIP2, A negative control PDZ protein. D, PSD-95 forms a complex with BCR and ABR in HEK293T cells. Cells doubly transfected (Trf) with EGFP-BCR/ABR and PSD-95 were immunoprecipitated (IP) with EGFP antibodies and immunoblotted with PSD-95 antibodies. Input (Inp), 5\%.E, F, PSD-95 forms a complex with BCR and ABR in the brain. The crude synaptosomal fraction of rat brain at indicated developmental stages were immunoprecipitated with BCR (1359) and ABR (1388) antibodies and immunoblotted with the indicated antibodies. S-SCAM, A negative control PDZ protein; IgG, control rabbit antibodies. Input (inp), 5\%, G, H, BCR and ABR do not depend on PSD-95 binding for synaptic localization. Cultured hippocampal neurons were transfected (DIV 17-19) with WT or mutant $B C R / A B R$ and monitored of the spine localization of the proteins, as determined by the spine/dendrite ratio. Data represent mean \pm SEM. $n=13-20$ neurons ( $20-25$ ratios per neuron); ${ }^{*} p<0.05$ (ANOVA for $B C R$, and Student's t test for ABR). Scale bars, $10 \mu \mathrm{m}$.

After $24 \mathrm{~h}$, the mice were exposed to two objects: $\mathrm{A}$ and $\mathrm{C}$, where $\mathrm{C}$ is a novel object. Object exploration was defined as each instance in which a mouse's nose touched the object or was oriented toward and within $2 \mathrm{~cm}$ to the object.

Open-field, elevated plus-maze, and rotarod assays. The open-field assay was performed in a white open-square chamber. The elevated plus-maze consisted of two open arms, two closed arms, and a center area, and was elevated to a height of $50 \mathrm{~cm}$ above the floor. Mice were placed in the center area and allowed to explore the space for $5 \mathrm{~min}$. For the accelerating rotarod test, mice were placed on a rotarod rotating at a slow speed $(\sim 4 \mathrm{rpm})$ for $30 \mathrm{~s}$. The speed was then gradually increased from 4 to $40 \mathrm{rpm}$ over $5 \mathrm{~min}$ (one trial per day), and the latencies to falling were measured.

\section{Results}

PSD-95 interacts with BCR and ABR but does not promote their synaptic localization

To better understand the role of PSD-95 in excitatory synaptic regulation, we screened PSD-95-interacting proteins using yeast two-hybrid assays, identifying BCR and ABR Rac GAPs as novel PSD-95-binding partners (Fig. $1 A$ ). The $\mathrm{C}$ termini of BCR and ABR interacted with the first two PDZ domains of PSD-95 and PSD-95 relatives (PSD-93/chapsyn-110, SAP97, and SAP102) (Fig. $1 B$ ). Mutant BCR and ABR with V-to-A point mutation of the C-terminal residue failed to bind PSD-95 family proteins. These interactions were further confirmed by glutathione $S$-transferase (GST) pull down and in vitro coimmunoprecipitation assays (Fig. 1C,D). In rat brains at postnatal days 7, 21, and 42, BCR formed a complex with PSD-95 (Fig. $1 E$ ). ABR was also in complex with PSD-95 (Fig. $1 F$ ). ABR, but not BCR, weakly associated with SAP97, contrary to the in vitro results.

We next tested whether PSD-95 promotes synaptic localization of $\mathrm{BCR}$ and $\mathrm{ABR}$. In cultured hippocampal neurons, the spine localization of a mutant BCR lacking PSD-95 binding (VA) was comparable with that of wild-type (WT) BCR (Fig. 1G). This 

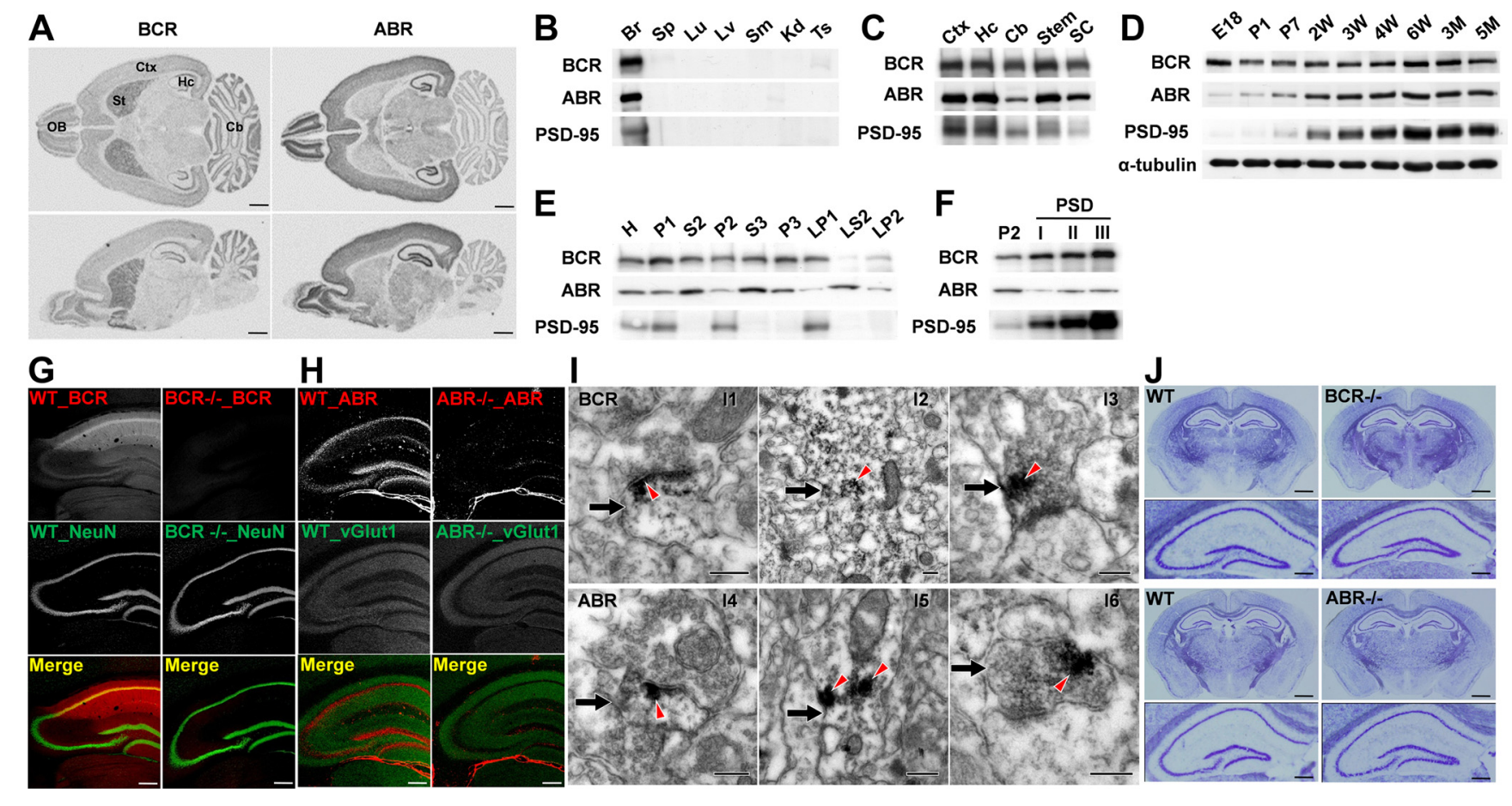

Figure 2. Expression patterns of $B C R$ and $A B R$ mRNAs and proteins. $A$, Widespread, but distinct, distribution patterns of $B C R$ and $A B R$ mRNAs in rat brains (P14), revealed by in situ hybridization. Ctx, Cortex; Cb, cerebellum; Hc, hippocampus; OB, olfactory bulb; St, striatum. Scale bar, $1 \mathrm{~mm} . B$, BCR and ABR proteins are mainly expressed in the brain. Br, Brain; Sp, spleen; Lu, lung; Lv, liver; Sm, skeletal muscle; Kd, kidney; Ts, testis. C, Expression of BCR and ABR proteins in various brain regions. Stem, Brainstem; SC, spinal cord. D, Expression of BCR and ABR proteins during rat brain development. W, Week; $M$, month. $E$, Widespread distribution of $B C R$ and $A B R$ in subcellular fractions of adult rat brain ( 6 weeks). H, Homogenates; $P 2$, crude synaptosomes; $S 2$, supernatant after $P 2$ precipitation; $S 3$, cytosol; $P 3$, light membranes; $L P 1$, synaptosomal membranes; $L S 2$, synaptosomal cytosol; $L P 2$, synaptic vesicle-enriched fraction. $F$, Greater enrichment of $B C R$ (relative to $A B R$ ) in PSD fractions, prepared by detergent extraction of the synaptosomal fraction, once with Triton X-100 (PSD I), twice with Triton X-100 (PSD II), once with Triton X-100 plus once with sarcosyl (PSD III). G, Abundant expression of BCR in the CA1 region of hippocampus, with successively lesser expression in the dentate gyrus (DG) and CA3 regions. WT and BCR ${ }^{-/-}$sections were doubly stained for BCR and NeuN (a neuron-specific protein). Scale bar, $250 \mu \mathrm{m}$. $\boldsymbol{H}$, Similar expression levels of ABR in DG and CA1 regions, with lower expression in CA3. Brain sections were doubly stained for BCR and vGlut1 (an excitatory presynaptic protein; NeuN was not used for antibody incompatibility). Scale bar, $250 \mu \mathrm{m}$. I, Ultrastructural localization of BCR and ABR mainly in spines and dendrites of CA1 pyramidal neurons. Signals for BCR (I1-I3) and ABR (I4 -I6), shown as dark DAB precipitates (red arrowheads), are mainly detected in dendritic spines (II, I4; arrows) and dendritic trunks (I2, I5; arrows), although occasionally observed in axon terminals (I3, I6; arrows). Scale bar, $0.2 \mu \mathrm{m}$. J, Normal gross morphologies of BCR ${ }^{-/-}$and ABR ${ }^{-/-}$brains, revealed by Nissl staining. Scale bars, 1 and $0.25 \mathrm{~mm}$.

suggests that BCR does not require PSD-95 binding for synaptic localization. Interestingly, deletion variants of BCR that lack the $\mathrm{N}$-terminal coiled coil (CC) domain showed significantly reduced spine localization. In addition, a BCR variant containing the $\mathrm{CC}+\mathrm{S} / \mathrm{T}$ kinase domains showed spine localization comparable with that of WT BCR, suggesting that the CC domain is important. ABR, which lacks the $\mathrm{CC}$ and S/T kinase domains, showed much lower levels of spine localization compared with BCR (Fig. $1 H$ ). As expected, WT and VA ABR showed similar levels of spine localization. These results suggest that BCR and ABR do not require PSD-95 binding for synaptic localization, and that the CC domain of BCR promotes spine localization.

\section{Expression patterns of $\mathrm{BCR}$ and $\mathrm{ABR} \mathrm{mRNAs}$ and proteins in} the brain

In situ hybridization revealed that BCR and ABR mRNAs are widely, but distinctly, expressed in various rat brain regions (Fig. $2 A)$. For instance, BCR mRNAs were more abundant in the striatum and cerebellum than in other regions, whereas ABR signals were stronger in forebrain regions, including the olfactory bulb, cortex, and hippocampus. In the hippocampus, BCR transcripts were weaker in the CA3 region, whereas ABR mRNAs were similarly expressed in all hippocampal subregions.

$\mathrm{BCR}$ and $\mathrm{ABR}$ protein expression was mostly restricted to the brain, not or barely being detected in other tissues (Fig. 2 B). BCR and $A B R$ proteins were detected in multiple brain regions, in- cluding the cortex, hippocampus, cerebellum, and brainstem, as well as the spinal cord (Fig. 2C). During rat brain development, BCR expression levels were initially high at a late embryonic (E18) stage and maintained at slightly decreased levels throughout postnatal brain development, whereas ABR expression gradually increased, similar to the expression pattern of PSD-95 (Fig. 2D).

Both BCR and ABR proteins were widely distributed in subcellular fractions of rat brain extracts (Fig. 2E), although BCR was more abundant in synaptic fractions, such as crude synaptosome (P2) and synaptic membrane (LP1) fractions, than was ABR. Consistently, BCR was highly enriched in PSD fractions, including the most detergent-resistant PSD III fraction, similar to PSD-95 (Fig. 2 F). In contrast, a relatively small portion of ABR was detected in PSD fractions, although it was present in PSD III.

Immunohistochemical analyses of brain slices from WT and knock-out (KO) mice revealed a differential expression of $\mathrm{BCR}$ and $\mathrm{ABR}$ proteins in hippocampal subregions. BCR protein was most abundant in the CA1 region and was expressed at successively lower levels in the dentate gyrus and the CA3 region (Fig. $2 G$ ), partly similar to the mRNA expression patterns (Fig. 2A). Substantial BCR signals were observed in the dendritic field of the CA1 region as well as the pyramidal cell body area. ABR proteins were expressed at similarly high levels in the dentate gyrus and CA1 regions, but were lower in the CA3 region (Fig. $2 H$ ). The 
weak ABR signals in the dendritic field may be because $A B R$, but not $B C R$, signals were amplified by tyramide.

Electron-microscopic analyses revealed that BCR proteins were detected in dendritic spines and trunks (Fig. 2I1,2), although signals at axon terminals were occasionally observed (Fig. 2I3). Overall, ABR distribution was similar to that of $B C R$, although $A B R$ was less frequently found in dendritic spines than was BCR (Fig. 2I4-6). $\mathrm{BCR}^{-1-}$ and $\mathrm{ABR}^{-1-}$ mice had normal gross morphology of the brain (Fig. $2 J$ ). Therefore, BCR and ABR mRNAs and proteins have overlapping as well as distinct cellular, subcellular, and ultrastructural distribution patterns in the brain.

\section{Deficiency of BCR or ABR in mice}

enhances basal Racl activity

BCR and ABR show Rac GAP activities in vitro and in vivo; for instance, monocytes derived from BCR and ABR double-null mice show enhanced basal Racl activity in assays pulling down GTP-bound Rac1 (Kaartinen et al., 2001). In $\mathrm{BCR}^{-1-}$ and $\mathrm{ABR}^{-\prime-}$ brain, basal Racl activities were significantly increased by $\sim 60 \%$, relative to WT brain (Fig. $3 A$ ). In addition, phosphorylation levels of PAK1 and PAK3, which correlate with Rac1 activity (Edwards et al., 1999; Bokoch, 2003), were significantly increased in $\mathrm{BCR}^{-1-}$ and $\mathrm{ABR}^{-1-}$ brain, whereas the total protein levels were unchanged (Fig. 3A). The phosphorylation levels of ERK1/2 (p42/ 44), which act downstream of PAK1 (Stockton et al., 2007), were also significantly increased, without a corresponding change in total ERK1/2. Phosphorylation levels of JNK or p38 MAPK were unchanged. In addition, expression of other synaptic proteins, including PSD-95 and glutamate receptors, in $\mathrm{BCR}^{-1-}$ and $\mathrm{ABR}^{-1-}$ mice, was unchanged (Fig. $3 B$ ). These results indicate that a deficiency of $B C R$ or $A B R$ in mice leads to enhanced basal Racl activity in the brain, and suggest that BCR and ABR function as important negative regulators of neuronal Rac1 activity.

\section{$\mathrm{BCR}^{-1-}$ and $\mathrm{ABR}^{-1-}$ mice show a}

small increase in dendritic spine

density but unaffected synaptic transmission

Because Racl positively regulates dendritic spines, we tested whether the enhanced basal Racl activity in $\mathrm{BCR}^{-1-}$ and $\mathrm{ABR}^{-1-}$ mice exerted a positive effect on dendritic spines. We visualized dendritic spines on the apical dendrites of CA1 pyramidal neurons by ballistic DiI delivery (Gan et al., 2000). BCR ${ }^{-/-}$ and $\mathrm{ABR}^{-1-}$ mice showed small, but significant, increases in spine density compared with WT animals (Fig. $4 A, B$ ), whereas

A

B
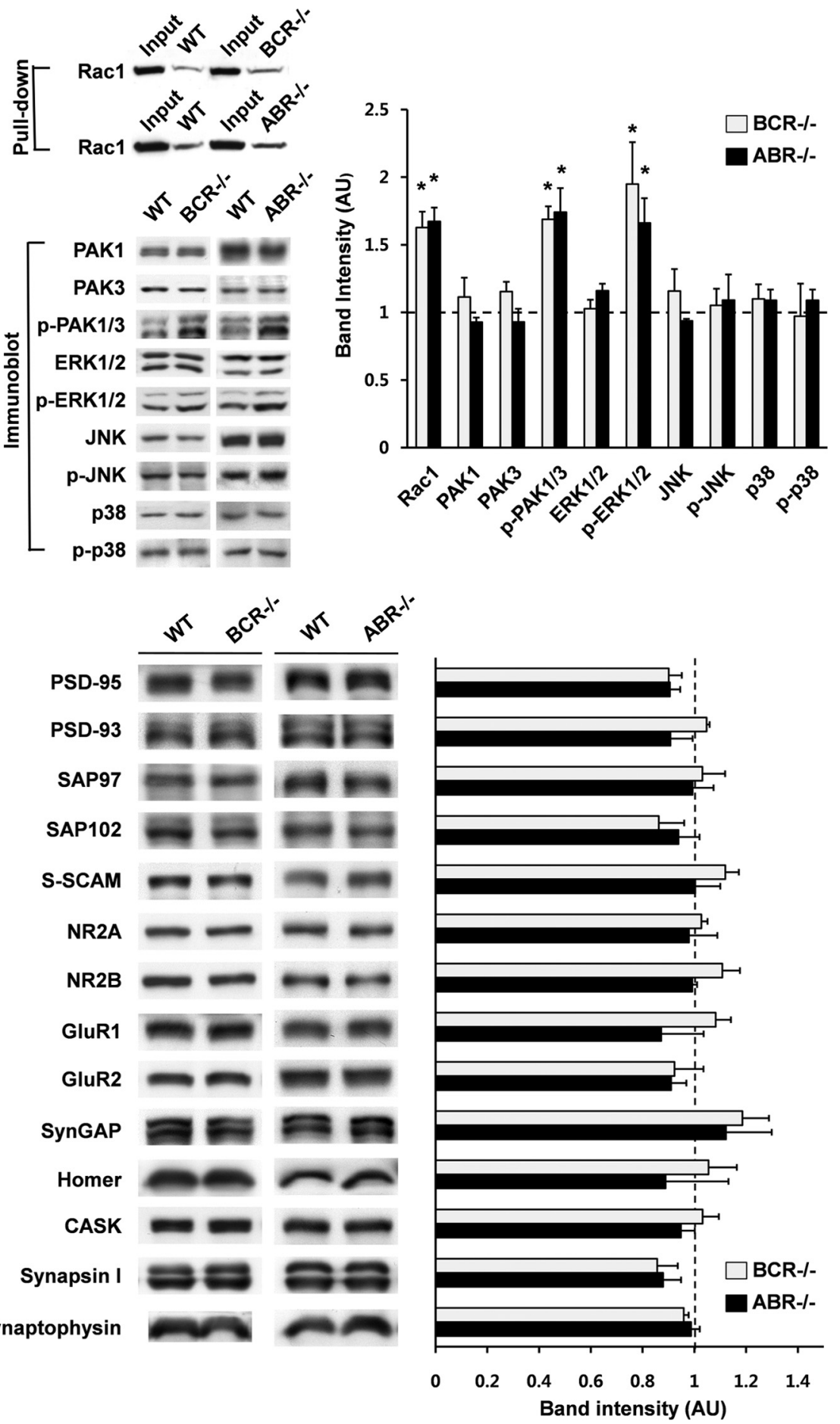

Figure 3. $B C R^{-1-}$ and $A B R^{-/-}$mice show enhanced basal Rac1 activity. A, Enhanced basal Rac1 activity and phosphorylation levels of PAK1/3 and ERK1/2, but not JNK and 338 MAPKs, in $\mathrm{BCR}^{-1-}$ and $A B R^{-1-}$ brains. Protein expression levels in $\mathrm{K} 0$ mice were normalized to those in WT mice. $n=3-4\left(3-4\right.$ weeks); ${ }^{*} p<0.05,{ }^{* *} p<0.01$; Student's $t$ test. $\boldsymbol{B}$, Normal expression levels of other synaptic proteins in $B C R^{-1-}$ and $A B R^{-1-}$ mice. $B C R$ and $A B R, n=3$. Error bars indicate SEM.

spine head area was unchanged (Fig. 4C), suggesting that BCR and ABR negatively regulate dendritic spine density.

We next tested whether these structural changes induce changes in synaptic transmission, by measuring mEPSCs. Both the frequencies and amplitudes of mEPSCs in $\mathrm{BCR}^{-1-}$ and $\mathrm{ABR}^{-1-} \mathrm{CA} 1$ pyramidal neurons were comparable with those of WT animals (Fig. $4 D-F$ ). In addition, the ratio of evoked AMPA receptor-mediated currents to NMDA receptor-mediated cur- 

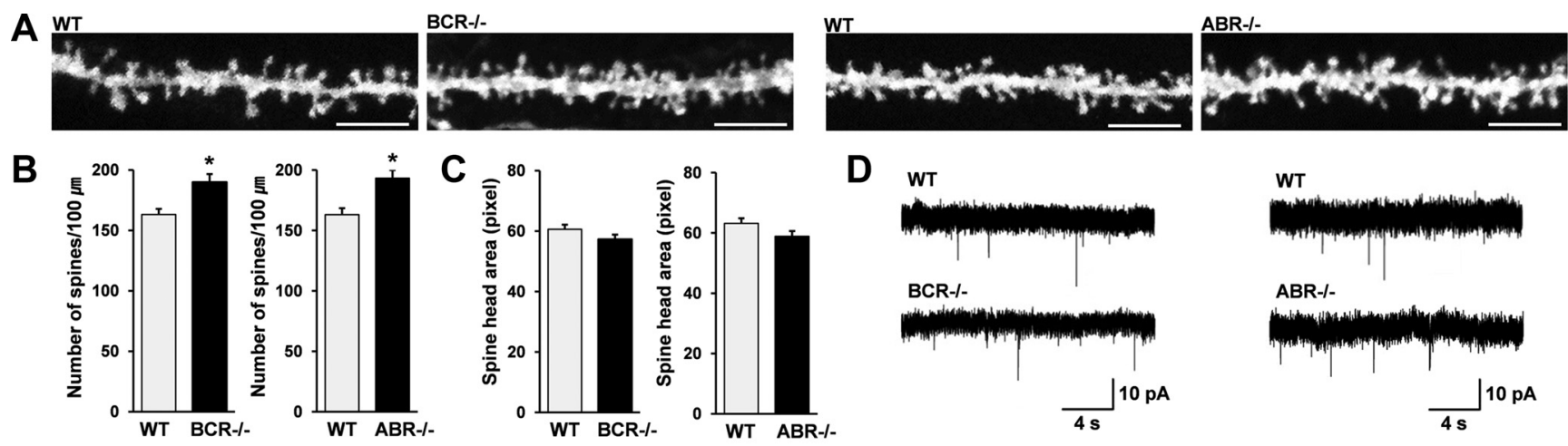

E
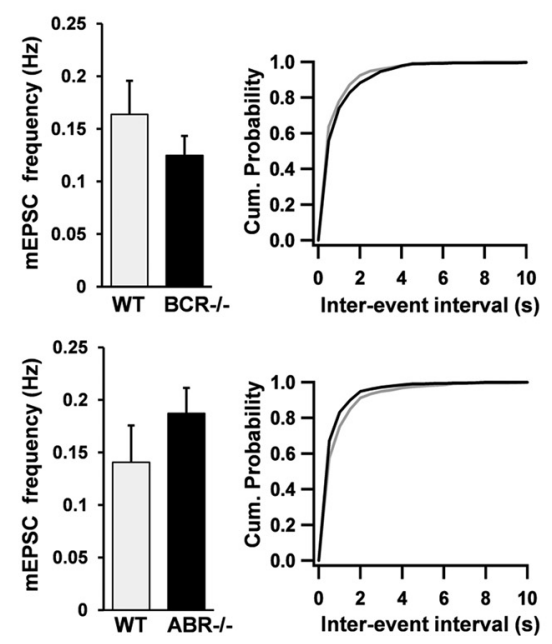

$F$
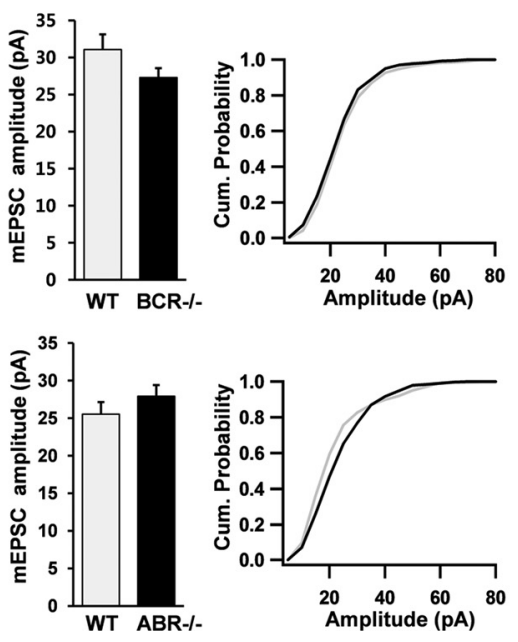

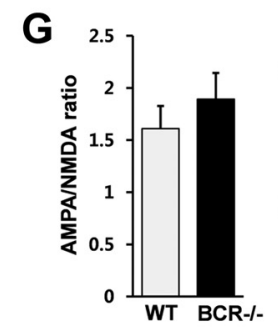

WT NMDA $+40 \mathrm{mV}$

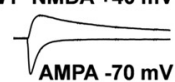

BCR -I-
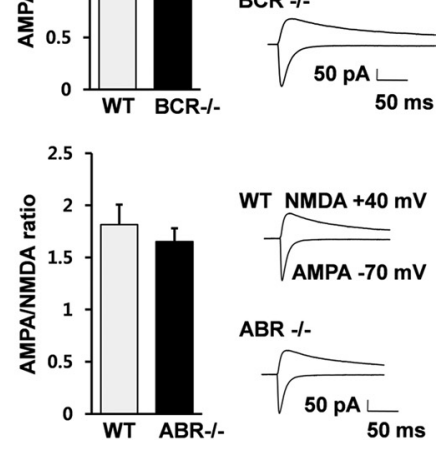

WT NMDA $+40 \mathrm{mV}$

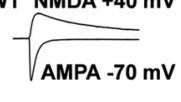

ABR -/-

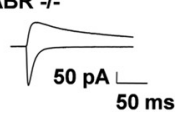

Figure 4. $B C R^{-1-}$ and $A B R^{-1-}$ mice show a small increase in spine density but normal synaptic transmission. $A-C$, Increased spine densities in apical dendrites of $B C R^{-1-}$ and $A B R^{-/-} C A 1$ pyramidal neurons, visualized by ballistic Dil delivery. Scale bar, $5 \mu \mathrm{m}$. Spine density, $n=21$ frames for $B C$ Rand 13 for $A B R ;$ spine head area, $n=18$ for $B C R$ and 15 for $A B R ; 3-5$ brains; $B C R, 6$ weeks; $A B R, 3$ weeks; ${ }^{*} p<0.05$, Student's $t$ test. $\boldsymbol{D}-\boldsymbol{F}$, Normal frequencies and amplitudes of $m E P S C s$ in $B C R^{-1-}$ and $A B R{ }^{-1-}$ CA1 pyramidal neurons. mEPSC traces $(\boldsymbol{D})$ and average values and cumulative distributions of mEPSC frequencies and amplitudes $(\boldsymbol{E}, \boldsymbol{F}$; black line, K0; gray line, WT) from WT and K0 neurons. BCR, WT, $n=24$ cells, 5 mice; K0, $n=19,4$; ABR, WT, $n=21,3 ; \mathrm{KO}$, $n=18,3$. G, Normal AMPA/NMDA ratios of evoked EPSCs at BCR ${ }^{-1-}$ and ABR ${ }^{-1-}$ SC-CA1 synapses. BCR, WT, $n=6$ cells, 4 mice; K0, $n=7,3 ; A B R$, WT, $n=9,6 ; K_{0}, n=8,6$. Error bars indicate SEM.

rents at Schaffer collateral (SC)-CA1 pyramidal neuron (CA1) synapses was not changed in $\mathrm{BCR}^{-1-}$ or $\mathrm{ABR}^{-1-}$ mice (Fig. $4 G$ ). Together with the absence of changes in evoked AMPA receptormediated EPSCs (see below), these results suggest that both AMPA receptor- and NMDA receptor-mediated excitatory synaptic transmission are normal in $\mathrm{BCR}^{-1-}$ and $\mathrm{ABR}^{-1-}$ mice. This suggests that genetic ablation of BCR or ABR induces a small increase in spine density without affecting excitatory synaptic transmission.

\section{$\mathrm{BCR}^{-1-}$ and $\mathrm{ABR}^{-1-}$ mice show reduced maintenance} of LTP

Filamentous actin is a major cytoskeletal element of dendritic spines (Matus et al., 1982; Nimchinsky et al., 2002; Hayashi and Majewska, 2005; Matus, 2005; Tada and Sheng, 2006; Alvarez and Sabatini, 2007; Schubert and Dotti, 2007; Sekino et al., 2007; Bourne and Harris, 2008; Cingolani and Goda, 2008). Actin filaments lie in the downstream of Racl and have been associated with various forms of synaptic plasticity (Tada and Sheng, 2006; Cingolani and Goda, 2008). Thus, we measured LTP and LTD at SC-CA1 synapses of $\mathrm{BCR}^{-1-}$ and $\mathrm{ABR}^{-1-}$ hippocampus, using extracellular recordings. The input-output ratio, determined by plotting the slopes of field EPSPs (fEPSPs) against fiber volley amplitudes, was unchanged at $\mathrm{BCR}^{-1-}$ and $\mathrm{ABR}^{-1-} \mathrm{SC}-\mathrm{CA} 1$ synapses compared with that in WT mice (Fig. $5 A, B$ ), suggesting that AMPA receptor-mediated basal synaptic transmission is normal in both $\mathrm{KO}$ mice. In addition, paired-pulse facilitation at SC-CA1 synapses was normal in $\mathrm{BCR}^{-1-}$ and $\mathrm{ABR}^{-1-}$ mice (Fig. $5 C, D$ ), suggesting that the probability of neurotransmitter release was unchanged.

Interestingly, LTP induced by theta-burst stimulation was reduced at both $\mathrm{BCR}^{-1-}$ and $\mathrm{ABR}^{-/-} \mathrm{SC}-\mathrm{CA} 1$ synapses compared with that at WT synapses, as determined by comparing fEPSP slopes at baseline and during the last $10 \mathrm{~min}$ of recordings (Fig. $5 E, F)(B C R, 143.9 \pm 9.6$ and $116.9 \pm 7.4 \%$ of baseline in WT and $\mathrm{KO}$, respectively; $p<0.05 ; n=11$ slices from 6 mice for WT and 20, 10 for $\mathrm{KO}$; $\mathrm{ABR}, 154.0 \pm 8.1$ and $112.5 \pm 9.5 \%$ of baseline in WT and KO, respectively; $p<0.01 ; n=12,7$ for WT and 17, 8 for $\mathrm{KO})$. In contrast, LTP magnitudes during the first $10 \mathrm{~min}$ after LTP at $\mathrm{BCR}^{-/-}$and $\mathrm{ABR}^{-/-}$SC-CA1 synapses were not significantly different from those at WT synapses, although a trend toward decreased LTP magnitudes was apparent, especially at $\mathrm{ABR}^{-/-}$synapses (Fig. 5E,F). These results suggest that a deficiency of BCR or ABR leads to a strong reduction in the maintenance, but not induction, of LTP. In contrast to LTP, LTD induced by low-frequency stimulation ( $1 \mathrm{~Hz}, 900$ pulses) was comparable in WT and $\mathrm{KO}\left(\mathrm{BCR}^{-1-}\right.$ and $\mathrm{ABR}^{-1-}$ ) animals (Fig. $5 G, H)$. These results suggest that BCR or ABR deficiency selectively suppresses LTP maintenance. 
Impaired spatial and object recognition memory in $\mathrm{BCR}^{-1-}$ and $\mathrm{ABR}^{-1-}$ mice Because LTP maintenance has been implicated in sustaining memory (Pastalkova et al., 2006; Sacktor, 2008), we tested spatial learning and memory in these animals using the Morris water maze (Morris, 1984). During the learning phase of the maze, $\mathrm{BCR}^{-1-}$ and $\mathrm{ABR}^{-1-}$ mice showed reduced learning relative to WT mice, exhibiting longer escape latencies at several data points (Fig. $6 A, E$ ). In the probe test, performed in a pool without the platform, $\mathrm{ABR}^{-1-}$ mice spent a reduced amount of time in the target quadrant compared with WT mice, whereas the time spent by $\mathrm{BCR}^{-1-}$ mice was not different from WT mice (Fig. $6 B, F$ ). Importantly, the number of exact crossings over the former location of the platform was substantially reduced in both $\mathrm{BCR}^{-1-}$ and $\mathrm{ABR}^{-1-}$ mice (Fig. $6 C, G$ ). No significant changes were observed in swimming speeds (Fig. $6 D, H)$. These results suggest that $\mathrm{BCR} /$ $A B R$ deficiency impairs spatial learning and memory.

We next tested object recognition, which measures hippocampus-dependent nonspatial visual-discrimination memory (Vnek and Rothblat, 1996). In the sample phase, during which $\mathrm{BCR}^{-1-}$ and $\mathrm{ABR}^{-1-}$ mice were exposed to two different objects ( $A$ and $B$ ), the mice spent equal amounts of time on each (Fig. 6I,J), indicating that the two objects were equally preferred. In addition, the total amount of time spent exploring the objects $(\mathrm{A}+\mathrm{B})$ was similar in $\mathrm{KO}$ and WT mice (supplemental Fig. S1A, available at www. jneurosci.org as supplemental material), suggesting that these mice have comparable levels of attention and motivation for the objects. When one of the two objects (B) was replaced with a new one (C) $24 \mathrm{~h}$ after the sample phase, WT mice spent more time in the novel object, whereas $\mathrm{BCR}^{-1-}$ and $\mathrm{ABR}^{-1-}$ mice show an equal preference for the two objects (A and $\mathrm{C}$ ) (Fig. $6 K, L)$. The total amounts of time spent exploring the objects $(\mathrm{A}+\mathrm{C})$ were not different between $\mathrm{KO}$ and WT mice (supplemental Fig. $S 1 B$, available at www. jneurosci.org as supplemental material). These results suggest that BCR/ABR deficiency impairs object recognition memory.

In the open-field test, $\mathrm{KO}$ and WT mice showed similar levels of total distance moved and time spent in the center zone, indicating that their motor activities and anxiety levels are similar (supplemental Fig. S2, available at www.jneurosci.org as supplemental material). In an elevated plus-maze, $\mathrm{KO}$ and WT mice spent comparable amounts of time in open arms and entered the open arms with similar frequencies (supplemental Fig. S3, available at www.jneurosci.org as supplemental material), suggesting normal levels of anxiety in these mice. In the accelerating rotarod SEM.

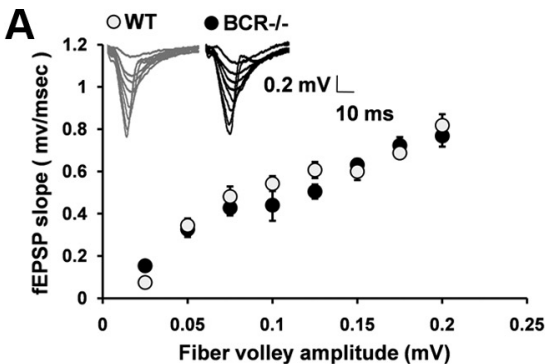

B
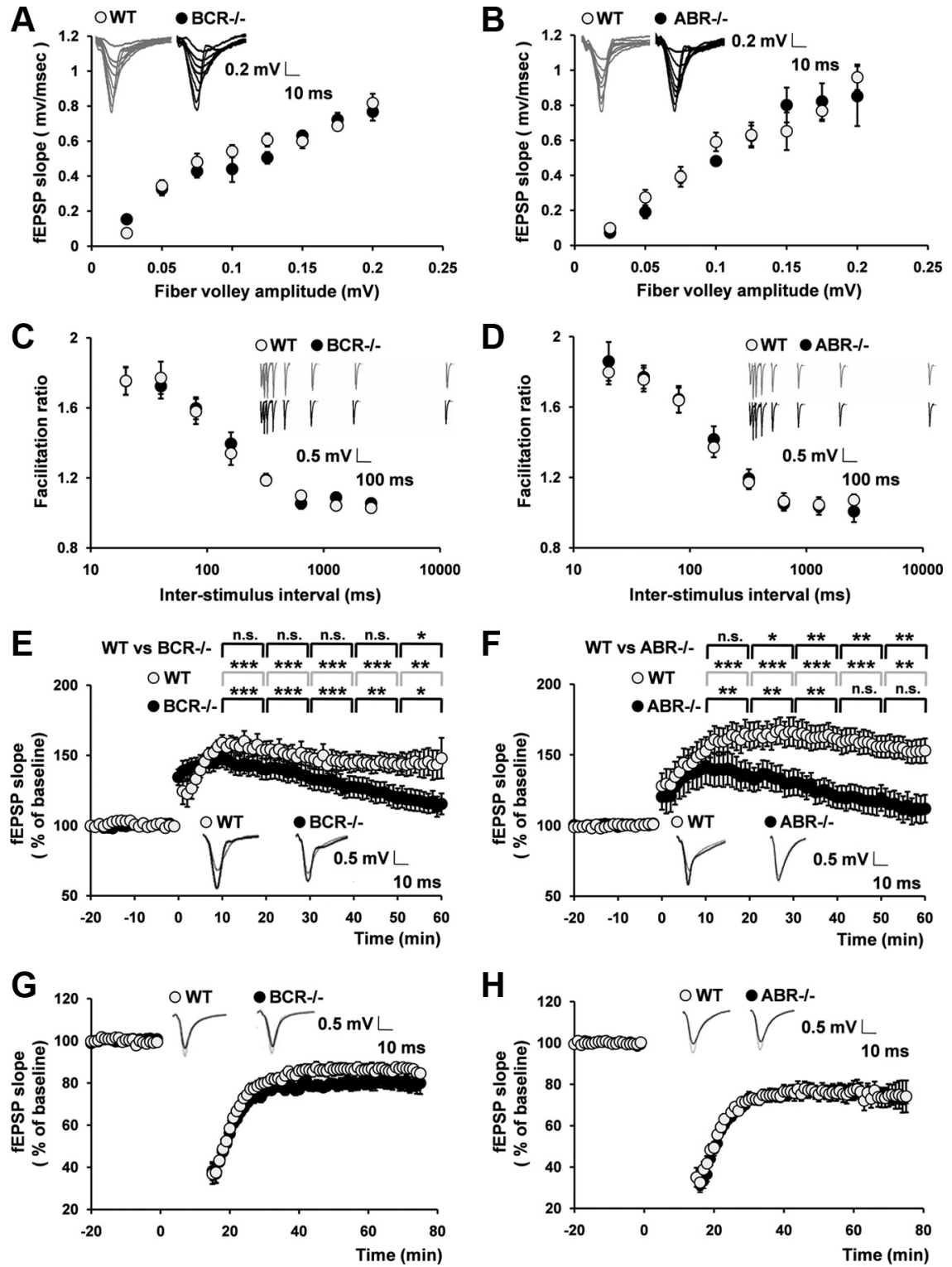

Figure 5. $B C R^{-1-}$ and $A B R^{-1-}$ mice show reduced maintenance of LTP but normal LTD. $A, B$, Normal AMPA receptormediated basal synaptic transmission at $\mathrm{BCR}{ }^{-1-}$ and $\mathrm{ABR}^{-1-} \mathrm{SC}-\mathrm{CA} 1$ synapses. $\mathrm{BCR}, n=14$ slices, 8 mice for both WT and K0; $A B R, n=10,8$. C, D, Normal paired-pulse facilitation (PPF) at $\mathrm{BCR}^{-1-}$ and $\mathrm{ABR}^{-1-} \mathrm{SC}-\mathrm{CA} 1$ synapses. BCR, WT, $n=9,4 ; \mathrm{KO}$, $n=16,6 ; \mathrm{ABR}, \mathrm{WT}, n=13,6 ; \mathrm{K} 0, n=12,6 . \boldsymbol{E}, \boldsymbol{F}$, Reduced maintenance of $\mathrm{LTP}$ induced by theta-burst stimulation at $\mathrm{BCR}^{-l-}$ and $A B R^{-/-}$SC-CA1 synapses. The gray and black traces were taken at 0 min and at the end of recording, respectively. The asterisks indicate statistical significances of the differences in fEPSP slopes between the indicated $10 \mathrm{~min}$ windows and the baseline before stimulation (for the bottom two rows) and between WT and $\mathrm{BCR}^{-1-}$ or $\mathrm{ABR}^{-1-}$ synapses (the top row). ${ }^{* * *} p<0.001$, ${ }^{* *} p<0.01,{ }^{*} p<0.05$, and n.s., not significant, Student's $t$ test. $\boldsymbol{G}, \boldsymbol{H}$, Normal LTD, induced by low-frequency stimulation, at $\mathrm{BCR}^{-1-}$ and $\mathrm{ABR}^{-1-} \mathrm{SC}-\mathrm{CA} 1$ synapses. BCR, WT, $n=15,8 ; \mathrm{K} 0, n=10,5 ; \mathrm{ABR}, \mathrm{WT}, n=10,4 ; \mathrm{K} 0, n=17,8$. Error bars indicate

assay, the initial latency to fall and the extent of daily motor learning were not different between KO and WT mice (supplemental Fig. S4, available at www.jneurosci.org as supplemental material), suggesting that BCR/ABR deficiency does not affect motor coordination.

\section{Discussion}

Previous studies of BCR have mainly focused on BCR involvement in immune regulation and leukemia development. Our study identifies a novel synaptic function of BCR and its close relative $A B R$, showing that these proteins are mainly expressed in the brain, where they are distributed to excitatory synapses and 

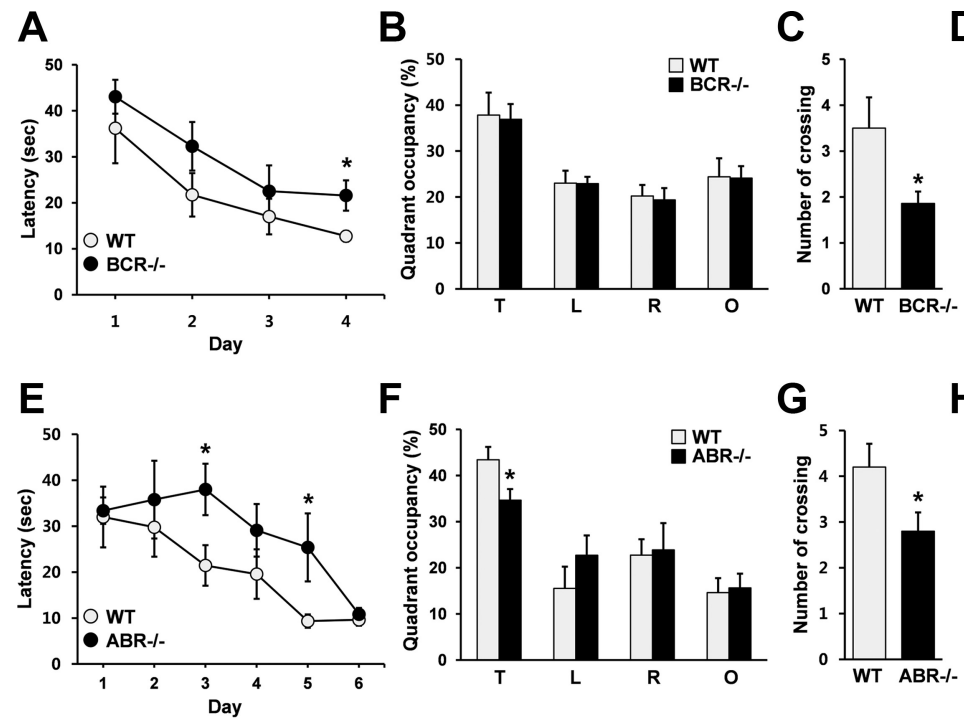

$\mathbf{F}$
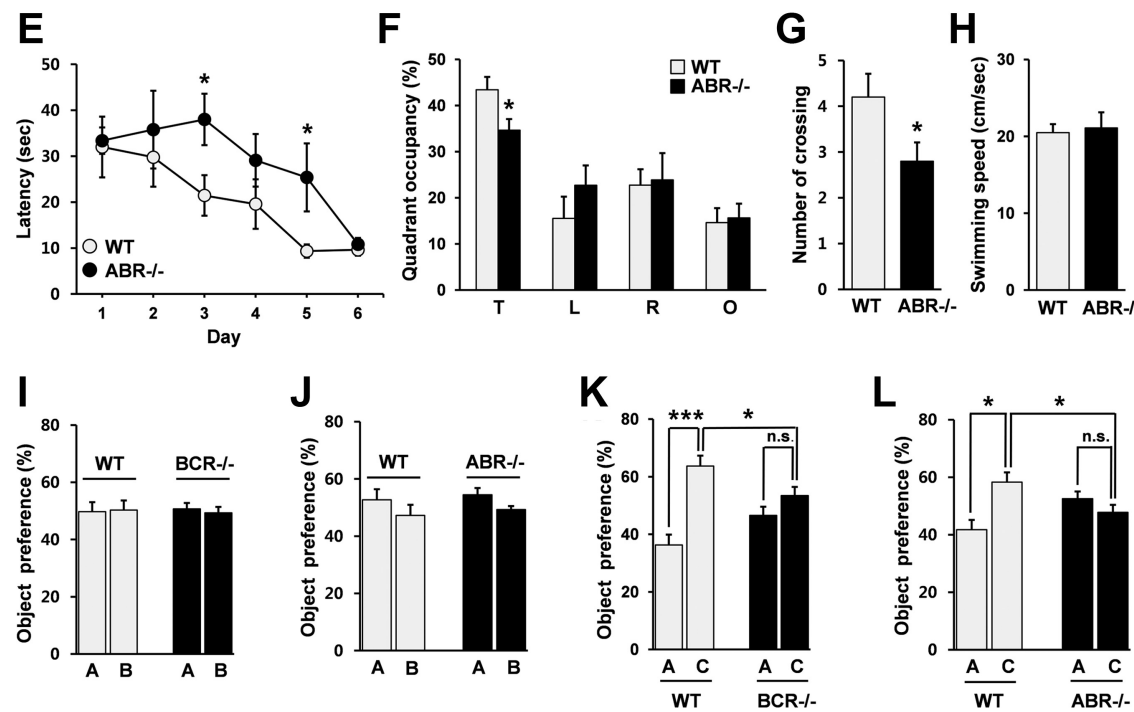

Figure 6. Impaired spatial learning and object recognition memory in $B C R^{-/-}$and $A B R^{-1-}$ mice. $\boldsymbol{A}, \boldsymbol{E}$, Impaired spatial learning of $B C R^{-1-}$ and $A B R^{-1-}$ mice in Morris water maze. $B C R, n=6$ for WT and 7 for $K 0 ; A B R, n=7$ for WT and KO; ${ }^{*} p<$ 0.05 , Student's t test. $B, F, A B R^{-1-}$, but not $B C R^{-1-}$, mice spend reduced amount of time in the target quadrant in the probe test. T, Target; $L$, left; $R$, right; 0 , opposite. ${ }^{*} p<0.05 . C, G, B C R^{-1-}$ and $A B R^{-1-}$ mice show reduced numbers of exact crossings over the former platform area in the probe test. ${ }^{*} p<0.05$. D, H, Normal swimming speeds in $B C R^{-1-}$ and $A B R^{-I-}$ mice. $\boldsymbol{I}, \boldsymbol{J}$, $B C R^{-1-}$ and $A B R^{-1-}$ mice spend equal amounts of time on the two objects $(A, B)$ during the sample phase of object recognition experiments. $B C R, n=11$ for WT and 12 for $K 0 ; A B R, n=10$ for WT and 9 for $K 0 . K, L, B C R^{-1-}$ and $A B R^{-1-}$ mice spend equal amounts of time on the two object $(\boldsymbol{A}, \boldsymbol{C})$, whereas WT mice prefer the novel object $(\boldsymbol{C})$ in the test phase of object recognition experiments. $\mathrm{BCR}, n=11$ for WT and 12 for $\mathrm{KO} ; \mathrm{ABR}, n=10$ for WT and 9 for $\mathrm{KO}$; ${ }^{* * *} p<0.001,{ }^{*} p<0.05$, n.S., not significant, Student's $t$ test. Error bars indicate SEM.

interact with PSD-95. Moreover, our data provide strong genetic evidence that BCR and ABR regulate synaptic Rac1 signaling, LTP maintenance, and spatial and object recognition memory. These results suggest the novel involvement of BCR and ABR in the regulation of synaptic signaling and plasticity, and related cognitive functions.

\section{Interaction of PSD-95 with BCR and ABR Rac GAPs}

Our study identifies a direct interaction of BCR and ABR with PSD-95, a key scaffolding protein of excitatory synapses. One known function of PSD-95 is that it promotes synaptic localization of interacting proteins. Our results, however, indicate that BCR and ABR do not require PSD-95 interaction for their synaptic localization. In this respect, BCR and ABR are similar to SPAR (spine-associated RapGAP), a regulator of dendritic spine morphology (Pak et al., 2001; Pak and Sheng, 2003) that directly interacts with PSD-95 but does not depend on PSD-95 interaction for spine targeting. An alternative function of PSD-95 is to couple interacting proteins with functionally related proteins. For instance, PSD-95 interacts with both NMDA receptors and nNOS (neuronal nitric oxide synthase) and promotes their functional coupling (Sattler et al., 1999).
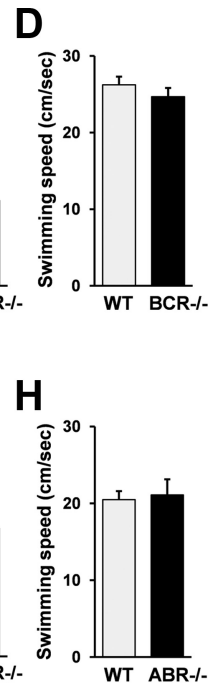

In this context, it should be noted that PSD-95 interacts with other Rac1-related signaling proteins, including Kalirin-7 (a Rac GEF) and IRSp53 (a Rac effector) (Penzes et al., 2001; Choi et al., 2005). It is thus conceivable that PSD-95 could bring two proteins with opposing functions (e.g., Kalirin-7 and BCR/ABR) into close proximity to promote tight local regulation of Racl activity. Alternatively, PSD-95 could link upstream regulators of Rac1, such as Kalirin-7 and BCR/ABR, with downstream Rac1 effectors, including IRSp53.

In addition to direct interactions, PSD-95 indirectly associates with various Rac1 signaling proteins; PSD-95 associates with $\beta$ Pix (a Rac GEF) and the Arp $2 / 3$ complex (a Rac effector) via GKAP (guanylate kinase-associated protein), Shank, and cortactin scaffolding proteins (Hering and Sheng, 2003; Park et al., 2003). In addition, PSD-95 is linked to Tiam1 (a Rac GEF), via NMDA receptors (Tolias et al., 2005). Thus, PSD-95 might function to organize synaptic Racl signaling in a multiprotein complex in which BCR and ABR function as negative regulators.

\section{Regulation of synaptic Racl signaling} and spine density by BCR and ABR

We found that, under basal conditions, a deficiency of BCR or ABR in mice leads to enhanced Racl activity. Enhanced basal Racl activity, in turn, was accompanied by increased levels of phosphorylated PAK1/3 and ERK1/2, which act downstream of Rac1 (Carlisle and Kennedy, 2005; Kennedy et al., 2005; Boda et al., 2006). These results provide strong genetic evidence that BCR and ABR function as important negative regulators of Racl activity.

BCR/ABR-deficient mice showed a small increase in spine density in the CA1 region of hippocampus, suggesting that BCR and ABR negatively regulate spine density. One mechanism that might underlie this regulation is the inhibition of Racl activity through BCR and ABR Rac-GAP domains, with subsequent suppression of Rac1-dependent F-actin polymerization and spine morphogenesis or maintenance. This possibility is supported by the observation that mice deficient for BCR or ABR show enhanced activity of Racl and PAK1/3, both of which positively regulate dendritic spines (Luo et al., 1996; Nakayama et al., 2000; Tashiro et al., 2000; Penzes et al., 2001; Zhang et al., 2003; Boda et al., 2004, 2006, 2008; Hayashi et al., 2004, 2007; Tashiro and Yuste, 2004; Carlisle and Kennedy, 2005; Zhang et al., 2005; Tada and Sheng, 2006; Kreis et al., 2007).

It should be noted, however, that the increase in spine density in $\mathrm{BCR}^{-1-}$ and $\mathrm{ABR}^{-1-}$ mice was small, and was not accompanied by a concomitant increase in spine head area or spontaneous/evoked excitatory synaptic transmission. These results suggest that compensatory mechanisms that partially uncouple enhanced Racl activity from spine density increases may be in- 
duced; thus, $\mathrm{BCR}$ or $\mathrm{ABR}$ may not be major regulators of spine density and synaptic transmission.

\section{Regulation of LTP maintenance by BCR and ABR}

$\mathrm{BCR}^{-1-}$ and $\mathrm{ABR}^{-1-}$ mice showed a marked decrease in the maintenance, but not induction, of LTP (but not LTD), with no effects on basal transmission or presynaptic release. A clue to the potential underlying mechanisms may come from the well known association between the actin cytoskeleton and LTP (Kim and Lisman, 1999; Krucker et al., 2000; Fukazawa et al., 2003; Matsuzaki et al., 2004; Okamoto et al., 2004; Lin et al., 2005; Kramár et al., 2006; Cingolani and Goda, 2008). Particularly relevant to our results is the report that inhibition of F-actin by low concentrations of actin-depolymerizing compounds such as latrunculin and cytochalasin, which preferentially inhibit the dynamic pool of actin filaments, selectively inhibit the maintenance of LTP (Krucker et al., 2000), whereas higher concentrations of these compounds block LTP induction (Kim and Lisman, 1999). More recent studies have shown that LTP induction increases the levels of phosphorylated PAK and cofilin in dendritic spines (Chen et al., 2007), and that distinct signaling pathways involving RhoA-ROCK-cofilin and Rac-PAK regulate the induction and maintenance phases of LTP, respectively (Rex et al., 2009). These results, together with the positive influence of Rac-PAK signaling on excitatory synaptic transmission (Boda et al., 2004; Wiens et al., 2005), suggest the hypothesis that the heightened Rac1 activity in the $\mathrm{BCR}^{-/-}$or $\mathrm{ABR}^{-/-}$brain may partly saturate signaling mechanisms required for the maintenance of LTP. Alternatively, enhanced basal Racl activity may evoke compensatory mechanisms that inhibit Racl activity under basal conditions in a homeostatic fashion; this, however, would likely have a negative influence on the Racl activity required for the stabilization of actin filaments during LTP maintenance. Possible compensatory mechanisms include enhanced activity or levels of Rac GAPs other than BCR and ABR, or reduced activity/levels of Rac GEFs such as Kalirin-7, $\beta$ Pix, and Tiam1.

\section{Regulation of learning and memory by BCR and ABR}

$\mathrm{BCR}^{-1-}$ and $\mathrm{ABR}^{-1-}$ mice showed impairments in spatial and object-recognition memory tasks. One of the most important questions in the field of memory-Does LTP maintenance sustain memory? - hints at a possible underlying mechanism for this observation. That LTP maintenance may indeed be involved in sustaining memory is supported by a large body of evidence (Reymann and Frey, 2007). For instance, $\mathrm{PKM} \zeta$, an atypical protein kinase $\mathrm{M}$, has been shown to be both necessary and sufficient for LTP maintenance (Pastalkova et al., 2006; Sacktor, 2008). It is thus conceivable that the reduced LTP maintenance in $\mathrm{BCR}^{-1-}$ and $\mathrm{ABR}^{-1-}$ mice might underlie the impaired memory in these animals.

It should be noted that excessive Racl activity in $\mathrm{BCR}^{-1-}$ and $\mathrm{ABR}^{-1-}$ mice had negative effects on synaptic plasticity and cognitive function. These consequences are similar to those of the opposite situation in which Rac1 signaling is suppressed, for example, by mutations in genes such as $\alpha$ Pix/ARHGEF6 and PAK3 that are known to be associated with mental retardation (Newey et al., 2005; Boda et al., 2006; Nadif Kasri and Van Aelst, 2008). Therefore, an appropriate level of Racl activity under basal conditions appears to be important in maintaining normal synaptic plasticity and cognitive functions. This view may also shed light on how defective regulation of Rac1 leads to cognitive dysfunction, an important question in the field of mental retardation.

Notably, a recent study showed that increased Rac1 activity promotes passive memory decay and interference-induced for- getfulness in Drosophila (Davis, 2010; Shuai et al., 2010). This study also showed that the PAK-LIMK-cofilin pathway downstream of Rac1 is important in mediating the effect of Racl. Interestingly, our mice showed enhanced Racl and PAK1/3 activities. Whether the underling molecular/neural mechanisms of the reduced performance of $\mathrm{BCR}^{-1-}$ and $\mathrm{ABR}^{-1-}$ mice in memory tasks have any shared aspects with those in flies remains to be determined.

\section{Similar phenotypes of $\mathrm{BCR}^{-1-}$ and $\mathrm{ABR}^{-1-}$ mice}

It is possible that the various phenotypes observed in $\mathrm{BCR}^{-1-}$ and $\mathrm{ABR}^{-1-}$ mice are attributable to domains other than the Rac GAP domain, such as the $S / T$ kinase domain of BCR, which is not present in $\mathrm{ABR}$. However, it should be noted that $\mathrm{BCR}^{-1-}$ and $\mathrm{ABR}^{-1-}$ mice showed many substantially overlapping phenotypes, including enhanced activation of Rac1, PAK1/3, and ERK1/2; increased spine density; reduced LTP maintenance; and impaired spatial and object recognition memory. These results strongly suggest that the shared phenotypes in $\mathrm{BCR}^{-1-}$ and $\mathrm{ABR}^{-I-}$ mice stem from their shared domains. $\mathrm{BCR}$ and $\mathrm{ABR}$ share the DH domain in addition to the Rac GAP domain. However, the DH domains of BCR and ABR do not exhibit Rho GEF activity (Cho et al., 2007), suggesting that this domain is unlikely to account for the phenotypes of $\mathrm{BCR}^{-1-}$ and $\mathrm{ABR}^{-1-}$ mice.

Another possibility is that the phenotypes observed in $\mathrm{BCR}^{-1-}$ and $\mathrm{ABR}^{-1-}$ mice are caused by long-term changes that accumulate during embryonic brain development. However, ABR expression is weak at the embryonic day 18 stage and sharply increases during the first few weeks of postnatal brain development (Fig. 2D), suggesting that the effect of ABR deletion is likely to be minimal during embryonic development. BCR expression is stronger at the embryonic day 18 stage than in postnatal stages; however, the overall phenotypic similarity between $\mathrm{BCR}^{-1-}$ and $\mathrm{ABR}^{-1-}$ mice suggests that $\mathrm{BCR}$ deficiencies at adult stages are likely to have a greater influence on the observed phenotypes of $\mathrm{BCR}^{-1-}$ mice. In addition, the fact that $\mathrm{BCR}^{-1-}$ and $\mathrm{ABR}^{-1-}$ mice showed enhanced and persistent Racl activation at adult stages during which synaptic plasticity and memory performances were measured further reduces the possibility of embryonic defects.

In conclusion, our study provides strong genetic evidence in support of the idea that BCR and ABR regulate synaptic Rac1 signaling, synaptic plasticity, and learning and memory. A direction for future studies would be to elucidate the detailed molecular mechanisms underlying these regulatory functions.

\section{References}

Alvarez VA, Sabatini BL (2007) Anatomical and physiological plasticity of dendritic spines. Annu Rev Neurosci 30:79-97.

Blanpied TA, Ehlers MD (2004) Microanatomy of dendritic spines: emerging principles of synaptic pathology in psychiatric and neurological disease. Biol Psychiatry 55:1121-1127.

Boda B, Alberi S, Nikonenko I, Node-Langlois R, Jourdain P, Moosmayer M, Parisi-Jourdain L, Muller D (2004) The mental retardation protein PAK3 contributes to synapse formation and plasticity in hippocampus. J Neurosci 24:10816-10825.

Boda B, Nikonenko I, Alberi S, Muller D (2006) Central nervous system functions of PAK protein family: from spine morphogenesis to mental retardation. Mol Neurobiol 34:67-80.

Boda B, Jourdain L, Muller D (2008) Distinct, but compensatory roles of PAK1 and PAK3 in spine morphogenesis. Hippocampus 18:857-861.

Bokoch GM (2003) Biology of the p21-activated kinases. Annu Rev Biochem 72:743-781.

Bourne JN, Harris KM (2008) Balancing structure and function at hippocampal dendritic spines. Annu Rev Neurosci 31:47-67. 
Buttery P, Beg AA, Chih B, Broder A, Mason CA, Scheiffele P (2006) The diacylglycerol-binding protein alphal-chimaerin regulates dendritic morphology. Proc Natl Acad Sci U S A 103:1924-1929.

Calabrese B, Wilson MS, Halpain S (2006) Development and regulation of dendritic spine synapses. Physiology (Bethesda) 21:38-47.

Carlisle HJ, Kennedy MB (2005) Spine architecture and synaptic plasticity. Trends Neurosci 28:182-187.

Chen LY, Rex CS, Casale MS, Gall CM, Lynch G (2007) Changes in synaptic morphology accompany actin signaling during LTP. J Neurosci 27:5363-5372.

Cho YJ, Cunnick JM, Yi SJ, Kaartinen V, Groffen J, Heisterkamp N (2007) Abr and Bcr, two homologous Rac GTPase-activating proteins, control multiple cellular functions of murine macrophages. Mol Cell Biol 27:899-911.

Choi J, Ko J, Racz B, Burette A, Lee JR, Kim S, Na M, Lee HW, Kim K, Weinberg RJ, Kim E (2005) Regulation of dendritic spine morphogenesis by insulin receptor substrate 53, a downstream effector of Racl and Cdc42 small GTPases. J Neurosci 25:869-879.

Chuang TH, Xu X, Kaartinen V, Heisterkamp N, Groffen J, Bokoch GM (1995) Abr and Bcr are multifunctional regulators of the Rho GTPbinding protein family. Proc Natl Acad Sci U S A 92:10282-10286.

Cingolani LA, Goda Y (2008) Actin in action: the interplay between the actin cytoskeleton and synaptic efficacy. Nat Rev Neurosci 9:344-356.

Davis RL (2010) Rac in the act of forgetting. Cell 140:456-458.

Diekmann D, Brill S, Garrett MD, Totty N, Hsuan J, Monfries C, Hall C, Lim L, Hall A (1991) Bcr encodes a GTPase-activating protein for p21rac. Nature 351:400-402.

Edwards DC, Sanders LC, Bokoch GM, Gill GN (1999) Activation of LIMkinase by Pak1 couples Rac/Cdc42 GTPase signalling to actin cytoskeletal dynamics. Nat Cell Biol 1:253-259.

Ethell IM, Pasquale EB (2005) Molecular mechanisms of dendritic spine development and remodeling. Prog Neurobiol 75:161-205.

Fukazawa Y, Saitoh Y, Ozawa F, Ohta Y, Mizuno K, Inokuchi K (2003) Hippocampal LTP is accompanied by enhanced F-actin content within the dendritic spine that is essential for late LTP maintenance in vivo. Neuron 38:447-460.

Gan WB, Grutzendler J, Wong WT, Wong RO, Lichtman JW (2000) Multicolor "DiOlistic" labeling of the nervous system using lipophilic dye combinations. Neuron 27:219-225.

Govek EE, Newey SE, Van Aelst L (2005) The role of the Rho GTPases in neuronal development. Genes Dev 19:1-49.

Groffen J, Stephenson JR, Heisterkamp N, de Klein A, Bartram CR, Grosveld G (1984) Philadelphia chromosomal breakpoints are clustered within a limited region, bcr, on chromosome 22. Cell 36:93-99.

Haditsch U, Leone DP, Farinelli M, Chrostek-Grashoff A, Brakebusch C, Mansuy IM, McConnell SK, Palmer TD (2009) A central role for the small GTPase Rac1 in hippocampal plasticity and spatial learning and memory. Mol Cell Neurosci 41:409-419.

Hayashi K, Ohshima T, Hashimoto M, Mikoshiba K (2007) Pak1 regulates dendritic branching and spine formation. Dev Neurobiol 67:655-669.

Hayashi ML, Choi SY, Rao BS, Jung HY, Lee HK, Zhang D, Chattarji S, Kirkwood A, Tonegawa S (2004) Altered cortical synaptic morphology and impaired memory consolidation in forebrain-specific dominantnegative PAK transgenic mice. Neuron 42:773-787.

Hayashi Y, Majewska AK (2005) Dendritic spine geometry: functional implication and regulation. Neuron 46:529-532.

Heisterkamp N, Stam K, Groffen J, de Klein A, Grosveld G (1985) Structural organization of the bcr gene and its role in the $\mathrm{Ph}^{\prime}$ translocation. Nature 315:758-761.

Heisterkamp N, Morris C, Groffen J (1989) ABR, an active BCR-related gene. Nucleic Acids Res 17:8821-8831.

Heisterkamp N, Kaartinen V, van Soest S, Bokoch GM, Groffen J (1993) Human ABR encodes a protein with GAPrac activity and homology to the DBL nucleotide exchange factor domain. J Biol Chem 268:16903-16906.

Hering H, Sheng M (2003) Activity-dependent redistribution and essential role of cortactin in dendritic spine morphogenesis. J Neurosci 23:11759-11769.

Kaartinen V, Gonzalez-Gomez I, Voncken JW, Haataja L, Faure E, Nagy A, Groffen J, Heisterkamp N (2001) Abnormal function of astroglia lacking Abr and Bcr RacGAPs. Development 128:4217-4227.

Kaartinen V, Nagy A, Gonzalez-Gomez I, Groffen J, Heisterkamp N (2002)
Vestibular dysgenesis in mice lacking Abr and Bcr Cdc42/RacGAPs. Dev Dyn 223:517-525.

Kennedy MB, Beale HC, Carlisle HJ, Washburn LR (2005) Integration of biochemical signalling in spines. Nat Rev Neurosci 6:423-434.

Kim CH, Lisman JE (1999) A role of actin filament in synaptic transmission and long-term potentiation. J Neurosci 19:4314-4324.

Kim MH, Choi J, Yang J, Chung W, Kim JH, Paik SK, Kim K, Han S, Won H, Bae YS, Cho SH, Seo J, Bae YC, Choi SY, Kim E (2009) Enhanced NMDA receptor-mediated synaptic transmission, enhanced long-term potentiation, and impaired learning and memory in mice lacking IRSp53. J Neurosci 29:1586-1595.

Kim Y, Sung JY, Ceglia I, Lee KW, Ahn JH, Halford JM, Kim AM, Kwak SP, Park JB, Ho Ryu S, Schenck A, Bardoni B, Scott JD, Nairn AC, Greengard $P$ (2006) Phosphorylation of WAVE1 regulates actin polymerization and dendritic spine morphology. Nature 442:814-817.

Kramár EA, Lin B, Rex CS, Gall CM, Lynch G (2006) Integrin-driven actin polymerization consolidates long-term potentiation. Proc Natl Acad Sci U S A 103:5579-5584.

Kreis P, Thévenot E, Rousseau V, Boda B, Muller D, Barnier JV (2007) The p21-activated kinase 3 implicated in mental retardation regulates spine morphogenesis through a Cdc42-dependent pathway. J Biol Chem 282:21497-21506.

Krucker T, Siggins GR, Halpain S (2000) Dynamic actin filaments are required for stable long-term potentiation (LTP) in area CA1 of the hippocampus. Proc Natl Acad Sci U S A 97:6856-6861.

Lamprecht R, LeDoux J (2004) Structural plasticity and memory. Nat Rev Neurosci 5:45-54.

Lin B, Kramár EA, Bi X, Brucher FA, Gall CM, Lynch G (2005) Theta stimulation polymerizes actin in dendritic spines of hippocampus. J Neurosci 25:2062-2069.

Luo L, Hensch TK, Ackerman L, Barbel S, Jan LY, Jan YN (1996) Differential effects of the Rac GTPase on Purkinje cell axons and dendritic trunks and spines. Nature 379:837-840.

Matsuzaki M, Honkura N, Ellis-Davies GC, Kasai H (2004) Structural basis of long-term potentiation in single dendritic spines. Nature 429:761-766.

Matus A (2005) Growth of dendritic spines: a continuing story. Curr Opin Neurobiol 15:67-72.

Matus A, Ackermann M, Pehling G, Byers HR, Fujiwara K (1982) High actin concentrations in brain dendritic spines and postsynaptic densities. Proc Natl Acad Sci U S A 79:7590-7594.

Morris R (1984) Developments of a water-maze procedure for studying spatial learning in the rat. J Neurosci Methods 11:47-60.

Nadif Kasri N, Van Aelst L (2008) Rho-linked genes and neurological disorders. Pflugers Arch 455:787-797.

Nakayama AY, Harms MB, Luo L (2000) Small GTPases Rac and Rho in the maintenance of dendritic spines and branches in hippocampal pyramidal neurons. J Neurosci 20:5329-5338.

Newey SE, Velamoor V, Govek EE, Van Aelst L (2005) Rho GTPases, dendritic structure, and mental retardation. J Neurobiol 64:58-74.

Nimchinsky EA, Sabatini BL, Svoboda K (2002) Structure and function of dendritic spines. Annu Rev Physiol 64:313-353.

Okamoto K, Nagai T, Miyawaki A, Hayashi Y (2004) Rapid and persistent modulation of actin dynamics regulates postsynaptic reorganization underlying bidirectional plasticity. Nat Neurosci 7:1104-1112.

Pak DT, Sheng M (2003) Targeted protein degradation and synapse remodeling by an inducible protein kinase. Science 302:1368-1373.

Pak DT, Yang S, Rudolph-Correia S, Kim E, Sheng M (2001) Regulation of dendritic spine morphology by SPAR, a PSD-95-associated RapGAP. Neuron 31:289-303.

Park E, Na M, Choi J, Kim S, Lee JR, Yoon J, Park D, Sheng M, Kim E (2003) The Shank family of postsynaptic density proteins interacts with and promotes synaptic accumulation of the beta PIX guanine nucleotide exchange factor for Rac1 and Cdc42. J Biol Chem 278:19220-19229.

Pastalkova E, Serrano P, Pinkhasova D, Wallace E, Fenton AA, Sacktor TC (2006) Storage of spatial information by the maintenance mechanism of LTP. Science 313:1141-1144.

Penzes P, Johnson RC, Sattler R, Zhang X, Huganir RL, Kambampati V, Mains RE, Eipper BA (2001) The neuronal Rho-GEF Kalirin-7 interacts with PDZ domain-containing proteins and regulates dendritic morphogenesis. Neuron 29:229-242.

Penzes P, Beeser A, Chernoff J, Schiller MR, Eipper BA, Mains RE, Huganir RL (2003) Rapid induction of dendritic spine morphogenesis by trans- 
synaptic EphrinB-EphB receptor activation of the Rho-GEF Kalirin. Neuron 37:263-274.

Penzes P, Cahill ME, Jones KA, Srivastava DP (2008) Convergent CaMK and RacGEF signals control dendritic structure and function. Trends Cell Biol 18:405-413.

Pilpel Y, Segal M (2005) Rapid WAVE dynamics in dendritic spines of cultured hippocampal neurons is mediated by actin polymerization. J Neurochem 95:1401-1410.

Rex CS, Chen LY, Sharma A, Liu J, Babayan AH, Gall CM, Lynch G (2009) Different Rho GTPase-dependent signaling pathways initiate sequential steps in the consolidation of long-term potentiation. J Cell Biol 186:85-97.

Reymann KG, Frey JU (2007) The late maintenance of hippocampal LTP: requirements, phases, "synaptic tagging," "late-associativity" and implications. Neuropharmacology 52:24-40.

Sacktor TC (2008) PKMzeta, LTP maintenance, and the dynamic molecular biology of memory storage. Prog Brain Res 169:27-40.

Saneyoshi T, Wayman G, Fortin D, Davare M, Hoshi N, Nozaki N, Natsume T, Soderling TR (2008) Activity-dependent synaptogenesis: regulation by a CaM-kinase kinase/CaM-kinase I/betaPIX signaling complex. Neuron 57:94-107.

Sattler R, Xiong Z, Lu WY, Hafner M, MacDonald JF, Tymianski M (1999) Specific coupling of NMDA receptor activation to nitric oxide neurotoxicity by PSD-95 protein. Science 284:1845-1848.

Sawallisch C, Berhörster K, Disanza A, Mantoani S, Kintscher M, Stoenica L, Dityatev A, Sieber S, Kindler S, Morellini F, Schweizer M, Boeckers TM, Korte M, Scita G, Kreienkamp HJ (2009) The insulin receptor substrate of $53 \mathrm{kDa}$ (IRSp53) limits hippocampal synaptic plasticity. J Biol Chem 284:9225-9236.

Schubert V, Dotti CG (2007) Transmitting on actin: synaptic control of dendritic architecture. J Cell Sci 120:205-212.

Sekino Y, Kojima N, Shirao T (2007) Role of actin cytoskeleton in dendritic spine morphogenesis. Neurochem Int 51:92-104.

Sheng M, Hoogenraad CC (2007) The postsynaptic architecture of excitatory synapses: a more quantitative view. Annu Rev Biochem 76:823-847.

Shuai Y, Lu B, Hu Y, Wang L, Sun K, Zhong Y (2010) Forgetting is regulated through Rac activity in Drosophila. Cell 140:579-589.

Soltau M, Richter D, Kreienkamp HJ (2002) The insulin receptor substrate IRSp53 links postsynaptic shank1 to the small G-protein cdc42. Mol Cell Neurosci 21:575-583.

Stockton R, Reutershan J, Scott D, Sanders J, Ley K, Schwartz MA (2007) Induction of vascular permeability: beta PIX and GIT1 scaffold the activation of extracellular signal-regulated kinase by PAK. Mol Biol Cell $18: 2346-2355$.
Tada T, Sheng M (2006) Molecular mechanisms of dendritic spine morphogenesis. Curr Opin Neurobiol 16:95-101.

Tan EC, Leung T, Manser E, Lim L (1993) The human active breakpoint cluster region-related gene encodes a brain protein with homology to guanine nucleotide exchange proteins and GTPase-activating proteins. J Biol Chem 268:27291-27298.

Tashiro A, Yuste R (2004) Regulation of dendritic spine motility and stability by Racl and Rho kinase: evidence for two forms of spine motility. Mol Cell Neurosci 26:429-440.

Tashiro A, Minden A, Yuste R (2000) Regulation of dendritic spine morphology by the rho family of small GTPases: antagonistic roles of Rac and Rho. Cereb Cortex 10:927-938.

Tolias KF, Bikoff JB, Burette A, Paradis S, Harrar D, Tavazoie S, Weinberg RJ, Greenberg ME (2005) The Racl-GEF Tiaml couples the NMDA receptor to the activity-dependent development of dendritic arbors and spines. Neuron 45:525-538.

Tolias KF, Bikoff JB, Kane CG, Tolias CS, Hu L, Greenberg ME (2007) The Racl guanine nucleotide exchange factor Tiaml mediates EphB receptordependent dendritic spine development. Proc Natl Acad Sci U S A 104:7265-7270.

Van de Ven TJ, VanDongen HM, VanDongen AM (2005) The nonkinase phorbol ester receptor $\alpha 1$-chimerin binds the NMDA receptor NR2A subunit and regulates dendritic spine density. J Neurosci 25:9488-9496.

van Galen EJ, Ramakers GJ (2005) Rho proteins, mental retardation and the neurobiological basis of intelligence. Prog Brain Res 147:295-317.

Vnek N, Rothblat LA (1996) The hippocampus and long-term object memory in the rat. J Neurosci 16:2780-2787.

Voncken JW, van Schaick H, Kaartinen V, Deemer K, Coates T, Landing B, Pattengale P, Dorseuil O, Bokoch GM, Groffen J (1995) Increased neutrophil respiratory burst in bcr-null mutants. Cell 80:719-728.

Wiens KM, Lin H, Liao D (2005) Rac1 induces the clustering of AMPA receptors during spinogenesis. J Neurosci 25:10627-10636.

Xie Z, Srivastava DP, Photowala H, Kai L, Cahill ME, Woolfrey KM, Shum CY, Surmeier DJ, Penzes P (2007) Kalirin-7 controls activity-dependent structural and functional plasticity of dendritic spines. Neuron 56:640-656.

Zhang H, Webb DJ, Asmussen H, Horwitz AF (2003) Synapse formation is regulated by the signaling adaptor GIT1. J Cell Biol 161:131-142.

Zhang H, Webb DJ, Asmussen H, Niu S, Horwitz AF (2005) A GIT1/PIX/ Rac/PAK signaling module regulates spine morphogenesis and synapse formation through MLC. J Neurosci 25:3379-3388.

Zhao L, Ma QL, Calon F, Harris-White ME, Yang F, Lim GP, Morihara T, Ubeda OJ, Ambegaokar S, Hansen JE, Weisbart RH, Teter B, Frautschy SA, Cole GM (2006) Role of p21-activated kinase pathway defects in the cognitive deficits of Alzheimer disease. Nat Neurosci 9:234-242. 